\title{
Juvenile Absence Epilepsy
}

National Cancer Institute

\section{Source}

National Cancer Institute. Juvenile Absence Epilepsy. NCI Thesaurus. Code C129868.

A subtype of idiopathic generalized epilepsy, whose manifestations occur around puberty, associated with mutation(s) in the EFHC1 gene, encoding EF-hand domain-containing protein 1. 